\title{
Cointegración \\ y simetrías en precios. \\ El caso del dulce \\ de leche en Santa Fe \\ y Rosario
}

E. D. Guiguet

Profesor Titular en el Departamento de Economía, Facultad de Ciencias Económicas de la UNL.

G. Rossini

Profesor Asociado (Becario posdoctoral CONICET) en el Departamento de Economía, Facultad de Ciencias Económicas de la UNL.

Palabras Clave - Key Words

- dulce de leche

- márgenes

- cointegración no lineal

- ajustes

- causalidad

- caramel jam - margins

- non lineal cointegration

- adjustments - causality

\section{Resumen}

Este estudio tiene como objetivo evaluar la forma en que están cointegrados los precios minoristas de un producto típico argentino como es el dulce de leche, y el de su insumo básico, la leche cruda, en los mercados de Santa Fe y Rosario en el período 1996-2005, y la simetría en su ajuste de corto plazo. Se utiliza un análisis de cointegración no lineal con los modelos TAR y MTAR. Los resultados confirman la existencia de cointegración en ambas ciudades, y asimetría en los ajustes en el corto plazo en Santa Fe. Además que la transmisión de los cambios de precios es más rápida cuando los márgenes de comercialización disminuyen que cuando se incrementan.

\section{Abstract}

The objetive of this study is to quantitatively evaluate retailers and producers prices cointegration of a typical argentine dairy product: caramel jam in Santa Fe and Rosario city markets for the period 1996-2005. A non linear cointegration approach is used with the TAR and MTAR models. A cointegrated relationship between both prices is found in both markets. As the short-term dynamics of the variables can only be applied to Santa $\mathrm{Fe}$, the results suggest that producer prices adjust to correct deviations in the long-run equilibrium. Another conclusion is that price transmission is faster when marketing margins shrink than when they increase. 